\title{
PENERAPAN MULTIMETODE UNTUK MENINGKATKAN PEMAHAMAN KONSEP MATEMATIS MAHASISWA
}

\author{
Anita Sri Rejeki Hutagaol*1,Melinda Rismawati², \\ Pendidikan Matematika,STKIP Persada Khatulistiwa Sintang \\ e-mail: *1boruhutagaolbest@gmail.com, ${ }^{2}$ melris_l@yahoo.com
}

\begin{abstract}
Understanding concepts is very important in learning mathematics. With deep understanding of concepts, students will be able to develop mathematical reasoning abilities and can solve mathematical problems easily. The purpose of this study is to improve the understanding of the mathematical concepts of PGSD undergraduate students using multimethods. This study is a Classroom Action Research (CAR) consisting of 2 cycles and each cycle consists of 4 stages, namely: planning, action, evaluation and reflection. The research subjects were S1 students of the PGSD Mipa class Semester 6 class, which amounted to 38 students. Data sources used are: observation sheets, interviews, tests and documentation. Data analysis techniques use an interactive model consisting of: data collection, data reduction, data presentation and conclusion drawing. The results showed that by applying multimethods, understanding students' mathematical concepts had increased. This is evidenced in the first cycle of understanding the mathematical concepts of students reached $77 \%$ and in the second cycle reached $100 \%$ so that the increase in understanding from cycle 1 to cycle 2 was $23 \%$.
\end{abstract}

\section{Keyword:Understanding concepts Mathematis, multimethods}

\begin{abstract}
Abstrak: Pemahaman konsep merupakan hal yang sangat penting dalam mempelajari matematika. Dengan pemahaman konsep yang dalam, siswa akan dapat mengembangkan kemampuan penalaran matematis serta dapat memecahkan masalah matematis dengan mudah. Tujuan dari penelitian ini adalah untuk meningkatkan pemahaman konsep matematis mahasiswa S1 Prodi PGSD dengan menggunakan multimetode. Penelitian ini merupakan Penelitian Tindakan Kelas (PTK) yang teridi dari 2 siklus`dan setiap siklus terdiri dari 4 tahapan, yaitu: perencanaan, pelaksanaan tindakan, evaluasi dan refleksi. Subjek penelitian adalah mahasiswa S1 prodi PGSD kelas Mipa Semester 6 yang berjumlah 38 mahasiswa. Sumber data yang digunakan yaitu: lembar observasi, wawancara, tes dan dokumentasi. Tekhnik analisis data menggunakan model interaktif yang terdiri dari: pengumpulan data, reduksi data, penyajian data dan penarikan kesimpulan. Hasil penelitian menunjukkan bahwa dengan menerapkan multimetode, pemahaman konsep matematis mahasiswa mengalami peningkatan. Hal ini dibuktikan pada siklus 1 pemahaman konsep matematis mahasiswa mencapai $77 \%$ dan pada siklus 2 mencapai $100 \%$ sehingga peningkatan pemahaman dari siklus 1 ke siklus 2 adalah $23 \%$.
\end{abstract}

Kata Kunci: Pemahaman Konsep Matematis, Multimetode 


\section{PENDAHULUAN}

Lembaga pendidikan tinggi sebagai salah satu unsur sistem pendidikan bertugas menyelenggarakan pendidikan yang membawa misi untuk menyiapkan peserta didik menjadi masyarakat yang memiliki kemampuan akademik serta mengembangkan dan menyebarluaskan ilmu pengetahuan, teknologi dan seni (IPTEKS) untuk meningkatkan taraf hidup masyarakat dan memperkaya kebudayaan nasional. Sejalan dengan fungsi pendidikan yang dikemukakan, Visi program studi PGSD STKIP Perdasa Khatulistiwa Sintang adalah menjadi program studi pendidikan dosen di Sekolah Dasar yang kompeten di Kalimantan Barat. Dalam rangka mencapai visi program studi PGSD, maka perlu kiranya berbagai inovasi dalam segala aspek terutama aspek proses pembelajaran. Mengingat tuntutan era globalisasi yang begitu luar biasa terhadap Perdosenan Tinggi, diharapkan Perdosenan Tinggi dapat menghasilkan keluaran (output) berkualitas sesuai dengan tuntutan masyarakat.

$$
\text { Kualitas lulusan Lembaga Pedidikan }
$$

Tinggi harus menguasai 4 kompetensi utama yaitu kompetensi profesional, kompetensi pedagogik, kompetensi sosial dan kompetensi kepribadian (UU No 14 Tahun 2005, tentang guru dan dosen). PGSD sebagai salah satu program studi yang dituntut dapat menciptakan lulusan yang berkualitas sesuai tuntutan masyarakat, sehingga selama menempuh perkuliahan adalah saatnya ditempa dalam rangka menanamkan 4 kompetensi utama sebagai seorang pendidik dan profesional di bidang ke-SD-an. Proses pembelajaran yang berkualitas selama perkuliahan berkontribusi dalam menanamkan kompetensi-kompetensi sebagai seorang pendidik seperti yang diamanatkan oleh UU No 14 Tahun 2005.

Menyikapi tuntutan tersebut, pendidik pada Lembaga Pendidikan Tinggi juga harus betul-betul menggaris bawahi apa yang diamanatkan oleh Undang- undang. Seorang dosen harus kreatif dan inovatif dalam merancang kegiatan perkuliahan, sehingga akan berdampak terhadap pengembangan kreativitas mahasiswa. Kapita Selekta Matematika SD merupakan salah satu mata kuliah wajib yang harus tempuh oleh mahasiswa S1 PGSD yang berbobot 2 SKS. Mata kuliah ini memberikan pemahaman perkembangan konsep dasar matematika SD yang diperlukan untuk calon guru SD baik secara konseptual maupun praktik. Dalam perkuliahan Kapita Selekta Matematika $\mathrm{SD}$, mahasiswa akan memperoleh pengalaman belajar secara pengkajian koseptual dan teori sekaligus dengan berbagai contoh penerapannya dalam kehidupan sehari-hari.

Latar belakang dilakukan pengembangan pembelajaran yang inovatif pada mata kuliah Kapita Selekta Matematika di SD adalah ketidakpuasan terhadap kualitas proses perkuliahan dan hasil belajar mahasiswa selama ini. Hal ini dibuktikan pada saat proses perkuliahan yang hanya menekankan pada menghafal konsep, mengerjakan tugas dalam rangka memenuhi tugas dosen dan perkuliahan berjalan satu arah. Salah satu indikator hasil belajar mahasiswa yang kurang memuaskan bisa dilihat berdasarkan tugas-tugas yang dikerjakan oleh mahasiswa yang hanya sekedar memenuhi 
tugas. Isi makalah yang dibuat oleh mahasiswa kebanyakan hanya copy paste dari modul dan buku yang sudah ada serta dari internet dan jarang sekali makalah dibuat oleh mahasiswa sendiri yang menggambarkan hasil pemikiran mahasiswa sendiri sebagai indikator kecakapan berpikir dan kemampuan mahasiswa dalam memahami konsep. Selain itu, pada saat mengerjakan soal-soal yang sifatnya prosedural dengan menggunakan satu konsep metematika yang sederhana, mahasiswa terlihat masih kesulitan. Hal ini disebabkan karena mahasiswa tidak memahami konsep dasar dari materi matematika yang sedang dipelajari. Mahasiswa juga sangat kesulitan dalam mengkaitkan konsep dengan kondisi yang ada di lingkungan nyata, mahasiswa belum menguasai materi yang akan diajarkan, kesulitan dalam pengembangan media yang sesuai dengan materi, dan kesulitan dalam penggunaan media tersebut.

Melihat kenyataan ini akan sulit mengharapkan mahasiswa nantinya ketika akan menjadi dosen mampu melaksanakan pembelajaran metematika yang inovatif dan sesuai dengan tuntutan kurikulum yang semakin lama semakin tinggi. Untuk meningkatkan kualitas proses dan hasil belajar, para ahli pembelajaran telah menyarankan penggunaan paradigma pembelajaran konstruktivistik selama kegiatan belajar-mengajar di kelas. Dengan perubahan paradigma belajar tersebut terjadi perubahan pusat pembelajaran dari belajar berpusat pada dosen kepada belajar berpusat pada mahasiswa. Dengan kata lain, ketika melaksanakan perkuliahan di kelas, dosen harus berupaya menciptakan kondisi lingkungan belajar yang dapat membelajarkan mahasiswa, dapat mendorong mahasiswa belajar, serta memberi kesempatan kepada mahasiswa untuk berperan aktif dalam mengkonstruksi konsepkonsep yang dipelajarinya seraya mengembangkan keterampilan berpikir yang dimiliki.

Apabila pada saat belajar mahasiswa yang semula hanya menerima materi dari pengajar, mencatat, dan menghafalkannya harus diubah menjadi sharing pengetahuan, mencari (inquiri), menemukan pengetahuan secara aktif sehingga diharapkan terjadi peningkatan pemahaman dan kecakapan berpikir. Tidak hanya itu, mahasiswa akan mempunyai kemampuan pemahaman konsep matematis dalam mata kuliah Kapita Selekta Matematika SD secara mendalam, dapat meningkatkan kemampuan penalaran, pemecahan masalah dan dapat meningkatkan kreatifitas ketika nantinya mahasiswa menjadi seorang guru.

Dalam pembelajaran, aspek pemahaman konsep dan aplikasinya merupakan hal yang sangat penting yang harus dimiliki mahasiswa selaku calon guru, karena hal ini akan menentukan keberhasilan pengajaran di kelas yang sebenarnya. Jika konsep dasar yang diterima siswa salah, maka sulit untuk memperbaiki kembali, terutama jika sudah diterapkan dalam menyelesaikan soal- soal matematika. Pengetahuan konsep yang kuat akan memberikan kemudahan dalam meningkatkan pengetahuan prosedural matematika. Karena prosedur- prosedur tanpa dasar konsep ini hanya merupakan aturan tanpa alasan yang akan membawa kepada kesalahan dalam matematika. 
Salah satu solusi untuk mencapai tujuan tersebut, diharapkan dosen mampu mengembangkan perangkat pembelajaran multimetode. Perangkat pembelajaran memiliki peranan yang sangat penting dalam pelaksanaan pembelajaran yaitu sebagai panduan bagi dosen dalam mengajar, mengingat proses pembelajaran, sebagai tolak ukur untuk mengevaluasi setiap hasil mengajarnya. Selain itu, jika perangkat pembelajaran disesuaikan dengan kebutuhan mahasiswa maka mahasiswa akan lebih mudah memahami materi pelajaran yang disampaikan oleh dosen dan ketertarikan mahasiswa dalam mempelajari mata kuliah tertentu akan tinggi.
Atas dasar uraian latar belakang inilah peneliti tertarik untuk melakukan penelitian dengan judul " Penerapan Multimetode Untuk Meningkatkan Pemahaman Konsep Matematis Mahasiswa". Sehingga dapat diketahui tingkat pemahaman konsep matematis mahasiswa dengan menggunakan multimetode.

\section{METODE}

Metode penelitian yang digunakan adalah Penelitian Tindakan Kelas. Adapun alur dalam penelitian ini adalah sebagai berikut :

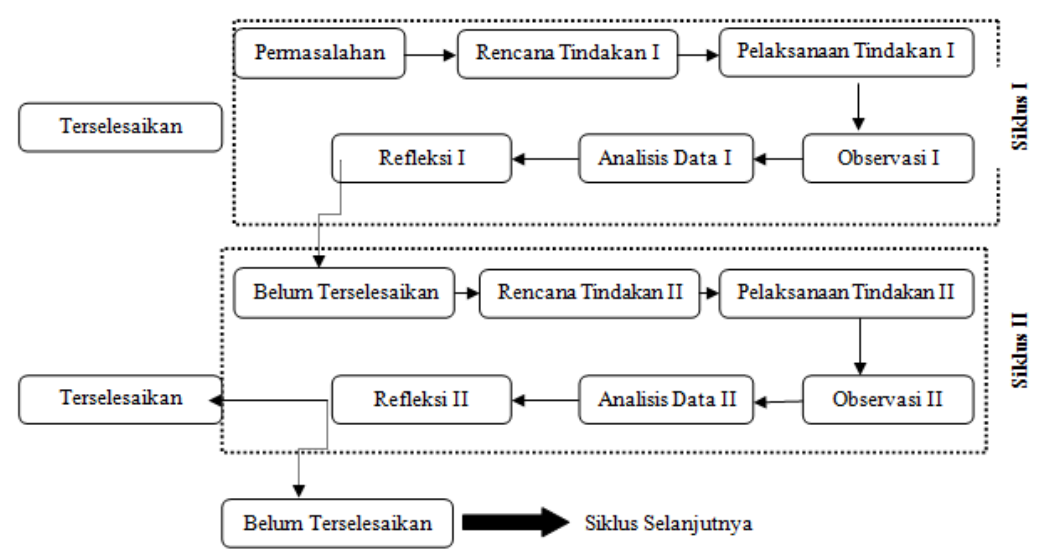

Gambar 1 Alur dalam Penelitian Tindakan Kelas (PTK)

Pelaksanaan penelitian tindakan ini

dilakukan melalui beberapa siklus. Siklus pertama untuk indikator pencapaian kompetensi: (1) Bilangan dan perkembangannya, (2) Klasifikasi bilangan,(3) Bilangan bulat, (4) Operasi penjumlahan dan sifat dari operasi penjumlahan bilangan bulat, (5) Operasi Pengurangan dan sifatnya serta
Operasi Perkalian dan sifatnya pada bilangan bulat, (6) Operasi pembagian dan sifatnya, dan (7) Penggunaan media pembelajaran pada operasi bilangan bulat.

\section{HASIL DAN PEMBAHASAN}

\section{Hasil}

Penelitian ini memiliki tahap-tahap penelitian yang berupa siklus. Prosedur yang dilaksanakan terdiri dari empat tahap untuk 
Tindakan, (3) Observasi, dan (4) Refleksi. berikut:

Kegiatan-kegiatan yang dilakukan pada

Tabel 1 Tahapan Pelaksanaan PTK

\begin{tabular}{|c|c|c|}
\hline \multirow{4}{*}{ 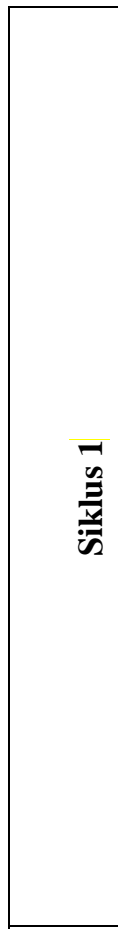 } & Perencanaan & $\begin{array}{l}\text { Permasalahan: } \\
\text { emahaman Konsep Matematis Mahasiswa Rendah } \\
\text { - } \quad \text { Menyusun Silabus,SAP dan RPS } \\
\text { - } \quad \text { Menyiapkan Alat Peraga } \\
\text { - Menyiapkan LKM } \\
\text { - Menyiapkan buku siswa } \\
\text { - } \quad \text { Menyusunan lembar observasi kegiatan guru dan siswa } \\
\end{array}$ \\
\hline & Tindakan & $\begin{array}{l}\text { - Menerapkan tindakan yang mengacu pada apa yang direncanakan sesuai } \\
\text { dengan indikator } \\
\text { Merangsang siswa untuk menginvestigasi, yang dapat mendukung } \\
\text { terbentuknya pemahaman konsep matematis lalu siswa menyelesaikan tugas } \\
\text { secara indivudu maupun kelompok dengan model pembelajaran } \\
\text { multimetode. }\end{array}$ \\
\hline & Pengamatan & $\begin{array}{ll}\text { - } & \text { Melakukan observasi dengan memakai lembar observasi } \\
\text { - } & \text { Menilai hasil tindakan dengan aturan penyekoran yang telah ditetapkan } \\
\end{array}$ \\
\hline & Refleksi & $\begin{array}{l}\text { - Melakukan evaluasi tindakan yang telah dilakukan } \\
\text { - Melakukan pertemuan untuk membahas hasil evaluasi tentang skenario, } \\
\text { - LKM, dan lain-lain } \\
\text { Memperbaiki pelaksanaan tindakan sesuai hasil evaluasi, untuk digunakan } \\
\text { pada siklus berikutnya }\end{array}$ \\
\hline \multicolumn{3}{|c|}{ Kesimpulan, saran dan rekomendasi untuk perbaikan pada siklus 2} \\
\hline \multirow{3}{*}{ 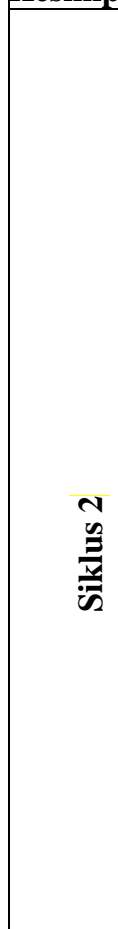 } & Perencanaan & $\begin{array}{l}\text { Permasalahan: } \\
\text { Kemampuan Pemahaman Konsep Matematis Siswa masih belum } \\
\text { terselesaikan pada siklus I } \\
\text { - Merencanakan KBM matematika } \\
\text { - Menyusun SAP } \\
\text { - Menyiapkan media pembelajaran } \\
\text { - Menyiapkan bahan diskusi } \\
\text { - Menyiapkan lembar observasi kegiatan guru dan siswa } \\
\text { - Menyiapkan format catatan pembelajaran angket respon siswa } \\
\end{array}$ \\
\hline & Tindakan & $\begin{array}{l}\text { - Menerapkan tindakan mengacu pada skenario yang direncanakan sesuai } \\
\text { dengan indikator } \\
\text { Membagi kelompok berdasarkan nilai tingkat kemampuan pemahaman } \\
\text { konsep matematis siklus } 1 \text {. } \\
\text { - Memberikan permasalahan yang dapat mendukung terbentuknya pemahaman } \\
\text { konsep matematis lalu siswa menyelesaikan tugas secara individu dan } \\
\text { selanjutnya direpresentasikan }\end{array}$ \\
\hline & Pengamatan & $\begin{array}{l}\text { - } \quad \text { Melakukan observasi dengan memakai lembar observasi } \\
\text { - } \quad \text { Menilai hasil tindakan dengan aturan penyekoran yang telah ditetapkan }\end{array}$ \\
\hline
\end{tabular}




\begin{tabular}{|c|l|l|}
\hline Refleksi & $\begin{array}{l}\text { Melakukan evaluasi tindakan yang telah dilakukan } \\
\text { Melakukan pertemuan untuk membahas hasil evaluasi tentang skenario, } \\
\text { LKM, dan lain-lain } \\
\text { Memperbaiki pelaksanaan tindakan sesuai hasil evaluasi, untuk digunakan } \\
\text { pada siklus berikutnya }\end{array}$ \\
\hline $\begin{array}{l}\text { Siklus-siklus berikutnya (apabila kemampuan pemahaman konsep matematis siswa pada siklus } 2 \text { lebih } \\
\text { tinggi dari siklus 1) }\end{array}$ \\
\hline Kesimpulan, saran dan rekomendasi \\
\hline
\end{tabular}

\section{Pembahasan}

Berdasarkan hasil lembar observasi aktifitas mahasiswa yang diisi oleh oerfer diperoleh : data hasil pengamatan aktivitas mahasiswa selama kegiatan pembelajaran, diperoleh persentase aktivitas mahasiswa pada Siklus 1 kegiatan 1 sampai 6 secara berturut-turut adalah $22,4 \%, 17,4 \%, 22 \%, 24,34 \%, 12,5 \%$, dan
$1,32 \%$. sedangkan pada siklus 2 Aktivitas mahasiswa pada kegiatan 1 sampai 6 secara berturut- turut adalah $23,03 \% ; 13,82 \% ; 27,3 \%$; $22,7 \% ; 12,17 \%$; dan 0, 99\%. Data aktifitas mahasiswa secara ringkas disajikan pada gambar 2 berikut.

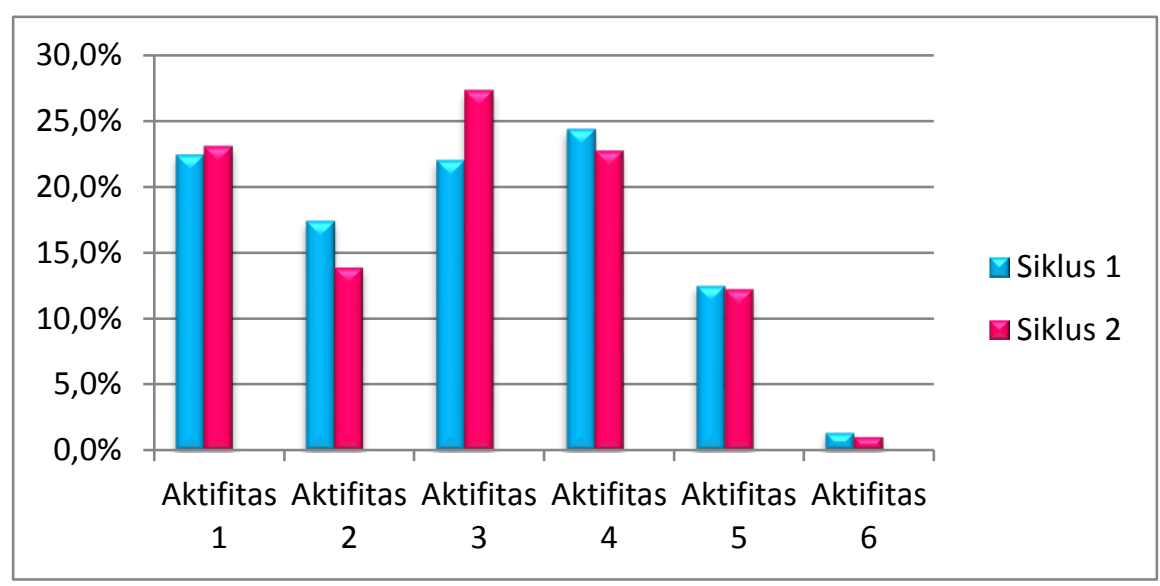

Gambar 2 Rekapitulasi Aktifitas Mahasiswa Siklus 1 dan 2

Merujuk pada hasil rekapitulasi aktivitas mahasiswa pada siklus 1 dan siklus 2, maka ktivitas mahasiswa berda pada kriteria sangat baik. Aktivitas dosen terhadap keterlaksanaan Pembelajaran menggunakan multimetode diamati setiap pertemuan oleh dua orang observer. menunjukkan bahwa ratarata poin untuk keterlaksanaan pembelajaran pada kegiatan pendahuluan adalah 4 poin dengan kriteria baik, pada kegiatan inti adalah 5 dengan kriteria sangat baik dan pada kegiatan penutup adalah 5 dengan kriteria sangat baik. Keterlaksanaan pembelajaran memenuhi kriteria sanagt baik. Berdasarkan rekapitulasi data hasil observasi aktivitas guru pertemuan ke- 3, menunjukkan bahwa poin rata- rata untuk keterlaksanaan pembelajaran pada kegiatan pendahuluan sebesar 5, pada kegiatan inti sebesar 5, dan pada kegiatan penutup sebesar 5. Keterlaksanaan pembelajaran memenuhi kriteria sangat baik. Ketiga bagian kegiatan pembelajaran juga 
memenuhi kriteria sangat baik. Berdasarkan hasil analisis observasi aktivitas dosen mengenai keterlaksanaan pembelajaran pada keseluruhan pertemuan diperoleh hasil bahwa keterlaksanaan pembelajaran melalui observasi aktivitas dosen telah memenuhi kriteria keterlaksanaan sangat baik.

Pntuk peningkatan pemahaman konsep mahasiswa diperoleh data pada tes pertama $77 \%$ mahasiswa yang memperoleh nilai $\geq 2.66$. pada tes ke- 2 jumlah mahasiswa yang memperoleh nilai $\geq 2.66$ sebesar $100 \%$.

Dari uraian data tersebut, terdapat peningkatan hasil belajar mahasiswa sebesar $23 \%$. Pada tes yang ke 2 seluruh mahasiswa memperoleh nilai $>2.66$, bahkan sebanyak 31,4\%- mahasiswa mendapatkan nilai sempurna yaitu 4.

Untuk peningkatan terhadap tiap indikator pemehaman konsep pada siklus 1 dan 2 memperlihatkan bahwa keterpenuhan indikator dapat menjelaskan sebuah defenisi dengan menggunakan bahasa sendiri menurut sifat-sifat/ciri-ciri yang esensial meningkat sebesar $29 \%$, indikator dapat membuat/menyebutkan contoh dan yang bukan contoh meningkat $21 \%$, dan indicator dapat menggunakan konsep untuk memecahkan masalah mengalami peningkatan sebesar $43 \%$.

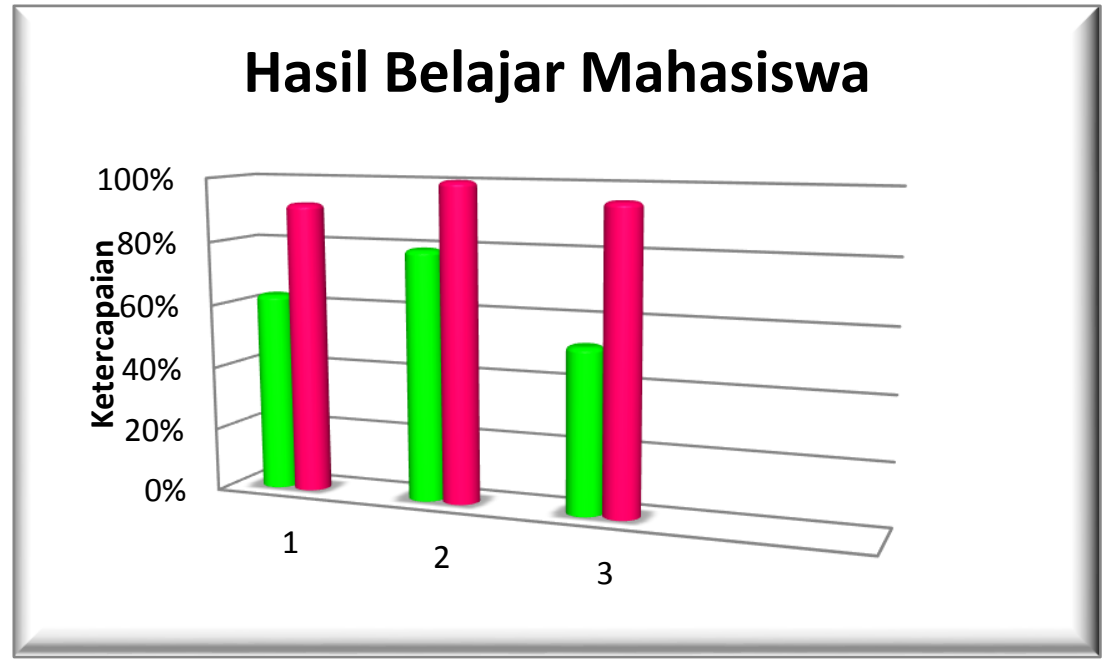

Gambar 3. Peningkatan keterpenuhan untuk setiap indikator pemahaman konsep

\section{SIMPULAN (PENUTUP)}

Karakteristik soal tes mengacu pada indikator pemahaman konsep matematis yaitu :1) mampu menjelaskan sebuah defenisi dengan kata-kata sendiri menurut sifat-sifat/ciri-ciri yang esensial, 2) mampu membuat/menyebutkan contoh dan yang bukan contoh, dan 3) mampu menggunakan konsep dalam menyelesaikan masalah. Aktifitas mahasiswa dan aktifitas dosen berdasarkan lembar observasi berada pada kategori sangat baik. hasil belajar mahasiswa meningkat sebesar $23 \%$ setelah 
diterapkannya multimetode dan pemahaman konsep mahasiswa juga mengalami peningkatan dari siklus 1 dan siklus 2 dengan rata-rata peningkatan sebesar $31 \%$.

\section{DAFTAR PUSTAKA}

Afrilianto. 2012. Peningkatan pemahaman konsep dan kompetensi strategis matematis siswa smp dengan pendekatan metaphorical thinking. Jurnal Ilmiah Program Studi Matematika STKIP Siliwangi Bandung, Vol 1 (2)

Arends . 2011. Learning to Teach. Ninth Edition. Central Connecticut State University

Hobri, H.2010. Metodologi Penelitian Pengembangan (Aplikasi pada Penelitian Pendidikan Matematika). Jember: Pena Salsabila.

Hudojo, H. 2005. Pengembangan Kurikulum dan Pembelajaran Matematika. Malang: IKIP Malang

Husna, A.R. 2010. Pengaruh Penggunaan Multimetode Dan Minat Belajar Terhadap Prestasi Belajar Materi Pemenuhan Kebutuhan Nutrisi. Tesis tidak diterbitkan. Universitas Sebelas Maret Surakarta.

Minarni, A. 2013. Pengaruh Pembelajaran Berbasis Masalah Terhadap Kemampuan Pemahaman Matematis dan Keterampilan Sosial Siswa SMP Negeri di Kota Bandung. Jurnal Pendidikan Matematika Paradikma. Vol 6 (2)

Nieveen. 2007. An Introduction to Educational Design Research. Enschede. Netzodruk.

Rahmawati, A. 2014. Meningkatkan Kemampuan Pemahaman Matematik Siswa SMP Melalui
Metode Penemuan Terbimbing. Vol 1 ISSN 2355-0473

Rohman dan Amri. 2013. Strategi dan Desain Pengembangan Sistem Pembelajaran. Jakarta: Prestasi Pustaka.

Trianto. 2011. Mendesain Model Pembelajaran Inovatif-Progresif. Jakarta: Kencana 